\title{
Desain Kapal untuk Wisata Rute Bangsring- Pulau Menjangan - Pulau Tabuhan
}

\author{
Khusnul Khotimah dan Hasanudin \\ Jurusan Teknik Perkapalan, Fakultas Teknologi Kelautan, Institut Teknologi Sepuluh Nopember (ITS) \\ Jl. Arief Rahman Hakim, Surabaya 60111 Indonesia \\ e-mail: hasanudin@na.its.ac.id
}

\begin{abstract}
Abstrak-Pantai Bangsring, Banyuwangi adalah objek wisata baru yang menarik, diresmikan oleh pemerintah Kabupaten Banyuwangi tahun 2014. Data dari kantor pengolah wisata Bangsring, jumlah pengunjung mencapai 230,872 orang pada tahun 2015 sampai awal tahun 2016 . Berdasarkan survey yang dilakukan di lokasi objek wisata Pantai Bangsring, dibutuhkan kapal wisata yang mendukung sarana transportasi wisata Bangsring untuk lebih meningkatkan kenyamanan penumpang saat berada di laut. Berdasarkan latar belakang tersebut maka dalam penelitian ini akan didesain kapal wisata untuk objek wisata Bangsring. Dalam desain ini dilakukan survey untuk mendapatkan Owner requirement, mencari data kapal pembanding. Dari hasil survey didapatkan payload $=16$ orang, Vs = 10 knot , dan jenis kapal katamaran fiber . Dan dari data kapal pembanding dilakukan analisa regresi linear untuk menentukan ukuran utama awal kapal sampai sesuai dengan batasan teknis, ukuran utama kapal yang optimal adalah (panjang) $L=11.3 \mathrm{~m}$, (lebar) $\mathrm{B}=6 \mathrm{~m}$, (sarat) $\mathrm{T}=0.6 \mathrm{~m}$, (tinggi) $\mathbf{H}=1.85 \mathrm{~m}$, (lebir demihull) $\mathrm{B} 1=1.2 \mathrm{~m}$. Hasil analisa ekonomi, biaya pembangunan kapal sebesar Rp. 732,918,893.35, biaya operasional sebesar Rp. 492,656,359 per tahun, dengan kelayakan investasi memenuhi NPV $>0$ sebesar Rp. 230,528,599.25, IRR > $11 \%$ sebesar $15.28 \%$, estimasi BEP akan dicapai dalam 4 tahun, dan harga tiket kapal Rp. 310,000 per orang untuk sekali trip. Dari ukuran utama diperoleh desain rencana garis dan rencana umum.
\end{abstract}

Kata Kunci- Katamaran, Fiberglass, Pantai Bangsring, Analisa Regresi.

\section{PENDAHULUAN}

$\mathrm{P}$ ANTAI Bangsring adalah salah satu objek wisata baru yang diresmikan oleh pemerintah Kabupaten Banyuwangi pada Agustus 2014. Terletak di Desa Bangsring Kecamatan Wongsorejo. Berdasarkan data dari kantor pengolah wisata Bangsring, pengunjung wisata mencapai 230,872 orang sampai pada awal tahun 2016. Berdasarkan hasil survey,terdapat peningkatan pengunjung sehingga dibutuhkan kapal wisata yang mendukung sarana transportasi wisata di Pantai Bangsring untuk lebih meningkatkan kenyamanan penumpang saat berada di laut.

Berdasarkan permasalahan diatas maka dalam penelitian ini akan dibuat desain kapal wisata yang sesuai dengan objek wisata Bangsring, dengan tetap memperhatikan keamanan dan kenyamanan penumpang, efisiensi bahan bakar, kecepatan kapal dan jangkauan pelayaran, serta sesuai dengan owner requirement. Selain itu juga akan dilakukan analisa teknis dan ekonomis meliputi : perhitungan hambatan, BHP, stabilitas,
LWT dan DWT, stabilitas, freeboard, trim, biaya produksi, biaya operasional, NVP, dan BEP.

Kapal jenis katamaran merupakan kapal memiliki dua lambung atau badan yang dihubungkan oleh geladak ditengahnya. Katamaran mempunyai geladak yang lebih luas dibandingkan dengan kapal monohull. Selain itu kapal katamaran juga mempunyai stabilitas yang lebih baik sehingga lebih nyaman digunakan.

\section{TINJAUAN PUSTAKA}

\section{A. Kapal Katamaran}

Katamaran merupakan kapal yang mempunyai dua lambung atau bridging platform ditengahnya. Bridging platform ini bebas dari permukaan air, sehingga slamming dan deck wetness kapal dapat dikurangi. Penentuan ketinggian struktur bagian atas dari permukaan air merupakan fungsi dari tinggi gelombang rute pelayaran yang dilalui. Kombinasi luas geladak yang besar dan berat kapal kosong yang rendah membuat kapal katamaran dapat diandalkan untuk transportasi muatan antar kota maupun pariwisata [1].

\section{B. Jenis kapal Katamaran}

Terdapat banyak jenis untuk lambung katamaran, secara umum terdapat tiga bentuk dasar dari katamaran, yaitu:

1. Asimetris dengan bagian dalam lurus

2. Asimetris dengan bagian luar lurus

3. Simetris

Perbedaan katamaran asimetris dan simetris terletak pada tekanan yang dialami oleh masing-masing lambung, bentuk lengkung akan mendapat tekanan yang lebih kecil karena aliran air terdistribusi mengikuti bentuk lengkung, sedangkan bentuk lurus mengalami tekanan yang besar. Karenanya untuk bentuk lambung simetris akan memberikan olah gerak kapal relative lebih baik dan hambatan total lebih kecil jika dibandingkan dengan asimetris.

\section{Material Fiberglass untuk kapal wisata katamaran}

Fiberglass merupakan gabungan dari resin dan serabut gelas yang mempunyai karaktek fisik berbeda, namun keduanya saling melengkapi [3].

Resin adalah material cair sebagai pengikat serat penguat yang memiliki kekuatan tarik serta kekakuan yang lebih rendah dibandingkan serat penguatnya [6].

Serat penguat adalah serat gelas yang memiliki kekakuan dan kekuatan tarik yang tinggi serta modulus elastisitas yang 
cukup tinggi. Adapun fungsi dari serat penguat meningkatkan kekuatan tarik dan kekakuan lengkung [10].

\section{METODLOGI PENELITIAN}

Dalam penelitian ini, desain kapal wisata dilakukan dengan identifikasi masalah sampai pada pencarian studi literatur yang mendukung serta pencarian data, yang kemudian dilakukan analisa teknis dan ekonomis pada desain kapal wisata, dan dihasilkan desain rencana garis dan rencana umum.

\section{TINJAUAN DAERAH WISATA}

\section{A. Wisata Pantai Bangsring}

Bunder merupakan kepanjangan dari Bangsring Under Water. Wisata ini terletak di Desa Bangsring Kecamatan Wongsorejo. Terletak di utara Banyuwangi sekitar $27 \mathrm{~km}$ dari pusat kota, tempat ini bisa ditempuh dalam waktu kira-kira 42 menit.

Rumah Apung "Bangsring Beach Underwater" dengan dasar laut yang eksotis tepat di bawah rumah apung serta pengunjung dapat berenang dengan hiu dipandu guide.Pantai Bangsring juga merupakan destinasi wisata underwater pertama di Banyuwangi yang dibuka tahun 2014 yang menawarkan keindahan alam bawah laut dan beberapa permainan seperti banana boat dan balon air.

\section{B. Wisata Pulau Tabuhan}

Lokasi pulau Tabuhan berada di desa Bengkak Kecamatan Wongsorejo Kabupaten Banyuwangi, Pulau Tabuhan terletak persis di tengah selat Bali yang memisahkan Pulau Jawa dan Pulau Bali.

Pulau ini memberikan keindahan tersendiri bagi para kitesurfer dengan kecepatan angin konstan 20-25 knot. Selain dapat menikmati pemandangan berupa gunung di daratan Pulau Jawa, terlihat pula hijaunya taman nasional Bali Barat (TNBB). Dua daratan ini memberikan pengaruh angin yang cukup kencang. Pulau yang memiliki luas sekitar $53.350 \mathrm{~m} 2$ atau kurang lebih 5 hektar, Pulau kecil yang masih belum berpenghuni ini banyak dikunjungi wisatawan.

\section{Wisata Pulau Menjangan}

Pulau Menjangan adalah pulau kecil yang terletak 5 mil barat laut pulau Bali dan merupakan bagian dari Taman Nasional Bali Barat. Pulau dengan luas sekitar 6.000 Ha adalah habitat menjangan atau rusa.

Terumbu karang yang berada di perairan Pulau Menjangan mencapai luas $260 \mathrm{Ha}$. Terumbu karang ini memiliki kisaran kedalaman 5-40 m dengan visibility antara 25-40 m. Sebagai kawasan wisata, Pulau Menjangan mulai dikenal sejak tahun 1978. Kawasan perairan ini dikenal dengan variasi ikan karang dan kegiatan wall dive, sehingga kawasan terumbu karang ini menjadi tempat tujuan wisata snorkeling dan diving.

\section{Rute dan Payload Kapal}

Berdasarkan potensi wisata yang ada di Bangsring, maka akan di pilih rute perjalanan wisata dari Bangsring Underwater, Pulau Menjangan, dan Pulau Tabuhan.

Gambar diatas menunjukkan rute pelayaran dari kapal wisata katamaran. Rute pelayaran yang direncanakan diawali dari pemberangkatan titik A (Pantai Bangsring) ke titik B (P. Menjangan) selama 40 menit, kemudian pengunjung bisa berwisata di $\mathrm{P}$. Menjangan selama 120 menit. Dan dilanjutkan dengan pemberangkatan dari titik B (P. Menjangan) ke titik C (P. Tabuhan) selama 35 menit, dan pengunjung bisa berwisata di pulau Tabuhan selama 60 menit. Setelah itu, trip berakhir dengan kembalinya kapal wisata menuju panati Bangsring yang ditempuh selama 20 menit. Jadi, total waktu yang diperlukan untuk satu kali trip kurang lebih 4.6 jam dengan kecepatan kapal 10 knot.

Dalam penentuan payload untuk desain kapal wisata katamaran kali ini, berdasarkan survey ditetapkan untuk jumlah penumpang termasuk crew kapal 16 orang (14 orang penumpang +2 crew kapal)

\section{ANALISIS TEKNIS - EKONOMIS DAN PEMBAHASAN}

\section{A. Tahap Desain Kapal}

Proses mendesain kapal adalah proses berulang, yaitu seluruh perencanaan dan analisis yang dilakukan secara berulang demi mencapai hasil yang maksimal ketika desain tersebut dikembangkan. Berdasarkan [9], tahapan desain terdiri dari empat yaitu :

1. Concept design atau konsep desain kapal merupakan tahap lanjutan setelah adanya Owner requirement.

2. Preliminary Design. Tahap ini dikembangkan hasil dari tahap conceptual dengan menetapkan alternative kombinasi yang jelas, sehingga pada akhirnya didapatkan gambaran utama kapal dan kecepatan servisnya.

3. Contract Design. Contract design biasanya menghasilkan satu set spesifikasi dan gambar, serta daftar peralatan permesinan.

4. Detail Design. Dalam stage ini gambar kerja dan kebutuhan data lainnya untuk membuat kapal dikembangkan.

\section{B. Penentuan Design Requirement}

Dalam Penentuan Owner Requirement Kapal wisata dilakukan dengan cara survey membagi kuisioner kepada pengelola dan pengunjung wisata. Kemudian dilakukan pengolahan data hasil kuisioner menggunakan metode 
Tabel 1. Data Kapal Pembanding

\begin{tabular}{|c|c|c|c|c|c|c|c|}
\hline No & $\begin{array}{l}\text { Nama } \\
\text { Kapal }\end{array}$ & $\begin{array}{c}\text { Kapasi } \\
\text { tas }\end{array}$ & $\begin{array}{c}\mathbf{L} \\
(\mathbf{m})\end{array}$ & B (m) & $\begin{array}{c}\mathbf{H} \\
(\mathrm{m})\end{array}$ & $\begin{array}{c}T \\
(\mathbf{m})\end{array}$ & Vs \\
\hline \multirow{2}{*}{1} & SUN CAT & & & & & & \\
\hline & & 30 & 14 & 9.1 & 1.8 & 1.2 & 8 \\
\hline \multirow[t]{2}{*}{2} & Solarwave & & & & & & \\
\hline & & 25 & 13.9 & 7.5 & 2 & 0.9 & 8 \\
\hline \multirow[t]{2}{*}{3} & Lazoon 380 & & & & & & \\
\hline & $4 C$ & 20 & 11.5 & 6.63 & 1.6 & 1.15 & 7.8 \\
\hline 4 & Mahe 36 & 23 & 11 & 5.9 & 1.7 & 1.15 & 10 \\
\hline 5 & Athena & 19 & 11.6 & 6.3 & 1.5 & 0.95 & 7 \\
\hline \multirow{2}{*}{6} & & & 11.9 & & & & \\
\hline & Linari 41 & 19 & 5 & 6.7 & 1.9 & 0.91 & 8 \\
\hline 7 & Lavezzi 40 & 17 & 11.9 & 6.5 & 1.9 & 1.1 & 8 \\
\hline 8 & Ecosol 34 & 20 & 10 & 4 & 1.4 & 0.7 & 8.1 \\
\hline \multirow{2}{*}{9} & Tema 360 & & 13.7 & & & & \\
\hline & Cat & 19 & 4 & 4.98 & 1.7 & 0.48 & 9 \\
\hline \multirow{3}{*}{10} & Catana 42 & & 12.5 & & & & \\
\hline & $O C$ & 18 & 8 & 6.86 & 1.8 & 0.6 & 11 \\
\hline & Bata & & & & & & \\
\hline 11 & Greine & 12 & 9.7 & 5 & 1.6 & 0.6 & 6 \\
\hline 12 & Ecocast & 10 & 8.00 & 4.50 & 0.90 & 0.30 & $\begin{array}{c}6.0 \\
0\end{array}$ \\
\hline 13 & Cat taxi & 12 & 9.80 & 5.80 & 1.00 & 0.30 & $\begin{array}{c}6.5 \\
0\end{array}$ \\
\hline 14 & $\begin{array}{l}\text { Ellips } 35 \\
\text { Glass }\end{array}$ & 9 & 10.5 & 3.2 & 1.3 & 0.5 & 8.5 \\
\hline 15 & $\begin{array}{l}\text { Bottom } \\
\text { boat }\end{array}$ & 10 & 8.2 & 4.6 & 1 & 0.4 & 7 \\
\hline
\end{tabular}

Tabel 2. Hasil Rekapitulasi Perhitungan Tebal Lapisan Fiber

\begin{tabular}{clcc}
\hline No. & \multicolumn{3}{c}{ Rekapitulasi tebal pelat } \\
\hline 1 & Keel plate & 15 & $\mathrm{Mm}$ \\
2 & Bottom & 12 & $\mathrm{Mm}$ \\
3 & Side Outboard & 10 & $\mathrm{Mm}$ \\
4 & Side Inboard & 14 & $\mathrm{Mm}$ \\
5 & Wet Deck & 7 & $\mathrm{Mm}$ \\
6 & Transom & 10 & $\mathrm{Mm}$ \\
7 & Bulwark & 6 & $\mathrm{Mm}$ \\
\hline \hline
\end{tabular}

Tabel 3. Stabilitas Kapal Untuk Beberapa Kondisi Muatan

\begin{tabular}{rlrrrr}
\hline \multicolumn{1}{c}{ Kriteria } & & \multicolumn{5}{c}{ Muatan } \\
& Satuan & $100 \%$ & $75 \%$ & $50 \%$ & $10 \%$ \\
\hline $\mathrm{A} \theta_{(30)} \geq$ & m.deg & 45.749 & 45.734 & 45.716 & 45.602 \\
3.1512 & & & & & \\
$\mathrm{~A} \theta_{(30-40)} \geq$ & m.deg & 13.349 & 13.215 & 13.081 & 12.831 \\
1.719 & & 1.517 & 1.505 & 1.494 & 1.472 \\
$\mathrm{GZ} \theta_{30} \geq 0,2$ & $\mathrm{M}$ & & & & \\
$\mathrm{A} \theta_{(40)} \geq$ & $\mathrm{m} . \operatorname{deg}$ & 59.098 & 58.948 & 58.797 & 58.437 \\
5.1566 & & 16.800 & 16.400 & 16.400 & 15.900 \\
$\theta \mathrm{GZ} Z_{\max } \geq 10^{\circ}$ & Deg & & & & \\
$\mathrm{GM} \geq 0.15$ & $\mathrm{M}$ & 15.093 & 15.398 & 15.696 & 16.160 \\
\hline \hline
\end{tabular}

statistic untuk mengetahui prosentase pilihan jawaban terbanyak. Dari analisa yang telah dilakukan maka ditentukan Owner Requirement Kapal:

1. Tipe Kapal: Kapal Katamaran Fiber tertutup

2. Kapasitas Penumpang Kapal wisata : 17 orang (14 penumpang +2 crew kapal)

3. Kecepatan kapal wisata : 10 knot
4. Rute Pelayaran : Bangsring - Pulau Menjangan - Pulau Tabuhan.

Dalam proses mencari ukuran utama kapal yang sesuai dengan Owner Requirement, maka salah satu metode yang dapat digunakan adalah dengan menggunakan data ukuran utama dari kapal pembanding, yang selanjutnya akan dilakukan analisa regresi linier untuk mencari ukuran utama awal kapal. Berikut data kapal pembanding yang digunakan :

Dari perhitungan regresi linear di atas didapatkan ukuran utama awal dasar sebagai berikut:

$$
\begin{aligned}
\mathrm{L} 0 & =11.09 \mathrm{~m} \\
\mathrm{~B} 0 & =6.43 \mathrm{~m} \\
\mathrm{~T} 0 & =0.64 \mathrm{~m} \\
\mathrm{H} 0 & =1.573 \mathrm{~m} \\
\mathrm{VS} & =10 \text { knots }=5.144 \mathrm{~ms}-1
\end{aligned}
$$

Namun, karena ukuran utama awal tidak memenuhi perbandingan ukuran utama kapal katamaran, maka dilakukan perubahan ukuran utama kapal :

$$
\begin{aligned}
& \mathrm{L}=11.3 \mathrm{~m} \\
& \mathrm{~B}=6 \mathrm{~m} \\
& \mathrm{~T}=0.6 \mathrm{~m} \\
& \mathrm{H}=1.85 \mathrm{~m} \\
& \mathrm{Vs}=10 \mathrm{knots}=5.144 \mathrm{~ms}-1
\end{aligned}
$$

\section{A. Perhitungn Hambatan}

Perhitungan hambatan berdasarkan [5], dilakukan dengan tujuan untuk mendapatkan daya mesin. Dengan demikian kapal dapat berlayar sesuai keinginan Owner. Komponen hambatan kapal katamaran:

Viscous interference resistance $(1+\beta \mathrm{k})$ : aliran disepanjang demihull berbentuk tidak simetris akibat penagruh keberadaan demihull

Wave making interference resistance $(\tau)$ : hasil dari dua buah lambung yang bergerak sejajar.

Rumus hambatan kapal katamaran berdasar penelitian Insal and Molland :

$\mathrm{R}_{\mathrm{T}}=2 \times(1 / 2) \times \rho \times \mathrm{V}^{2} \times$ WSA $\times \mathrm{C}_{\text {Tcat }}=3.49 \mathrm{kN}$

$\mathrm{C}_{\text {Tcat }}=(1+\beta \mathrm{k}) \times \mathrm{C}_{\mathrm{F}}+\tau \mathrm{C}_{\mathrm{W}}=0.0085$

\section{B. Perhitungan Daya Gerak Kapal}

Setelah nilai hambatan total (RT) diketahui langkah selanjutnya adalah melakukan perhitungan power berdasarkan [4] yang dibutuhkan untuk menggerakkan kapal. Variabel perhitungan power kapal terdiri dari:

$$
\begin{aligned}
\mathrm{EHP} & =\mathrm{Rt} . \mathrm{Vs}=17.97 \mathrm{~kW} \\
\mathrm{DHP} & =\mathrm{EHP} / \eta \mathrm{D}=32.98 \mathrm{~kW} \\
\mathrm{BHP} & =\mathrm{DHP}+(\mathrm{X} \% \mathrm{DHP} \\
& =37.932 \mathrm{~kW}
\end{aligned}
$$

\section{Perhitungan berat penumpang dan consumbale}

Menurut [7] kebutuhan bahan bakar dipengarui oleh konsumsi rata-rata bahan bakar dari mesin utama. Selain itu, kebutuhan bahan bakar dipengaruhi oleh lama berlayar. Adapun perhitungan berat bahan consumbale sebagai berikut :

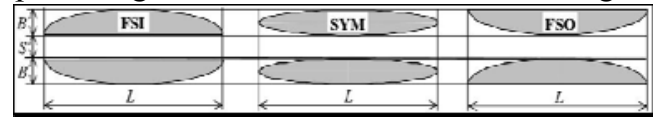


Gambar 1. Jenis Lambung Katamaran [1]

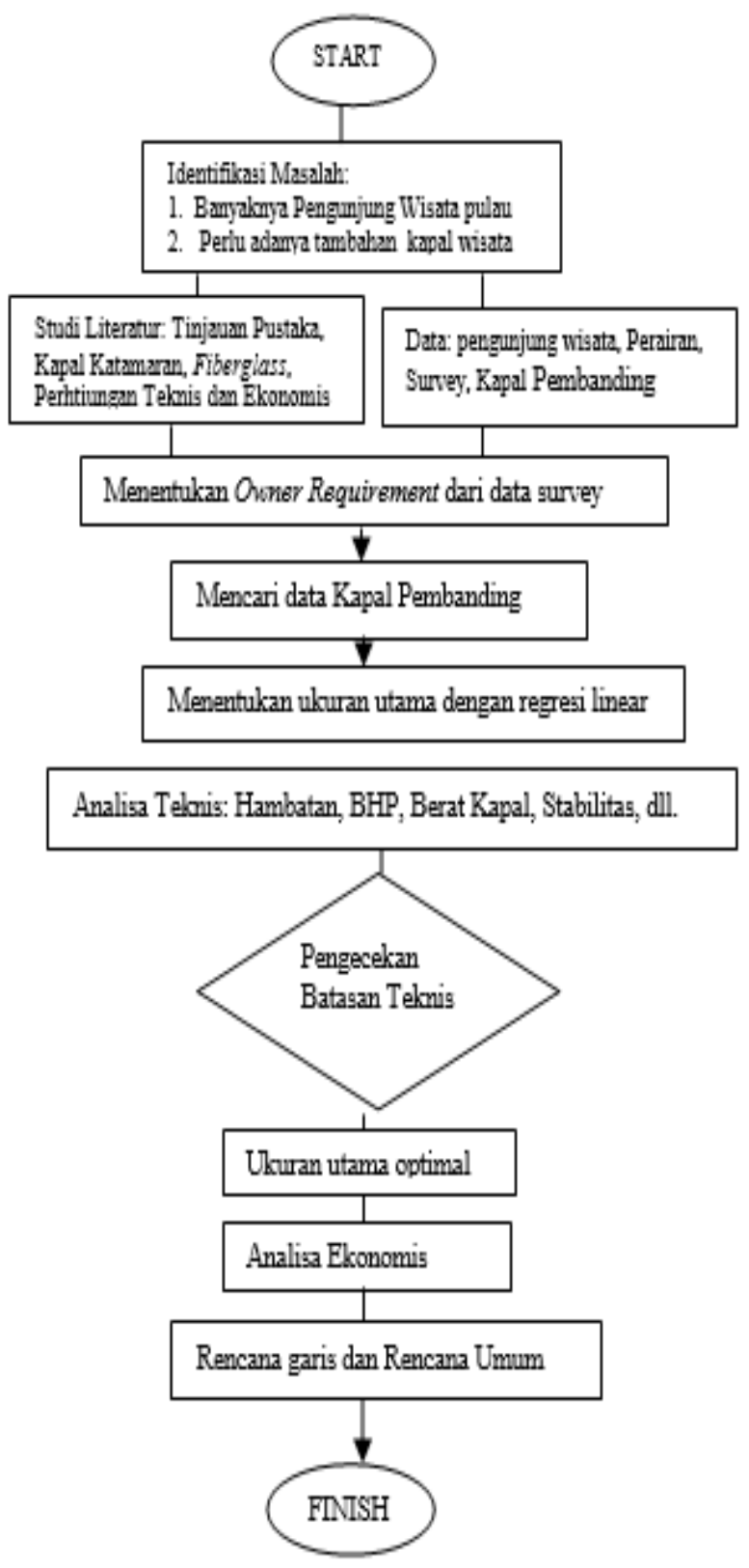

Gambar 2. Tahapan Penelitian

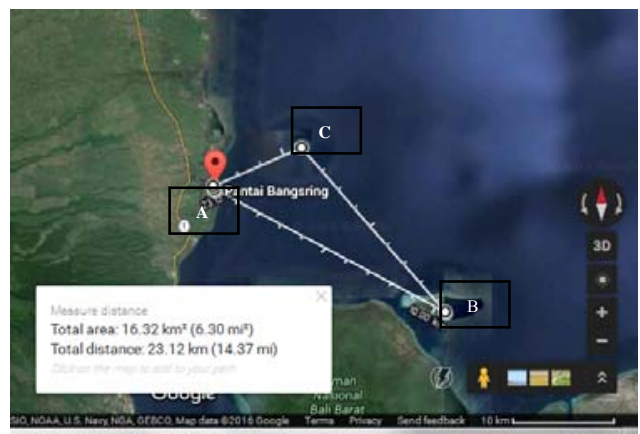

Gambar 3. Rute Pelayaran Kapal Wisata Katamaran (sumber : Google.Map.com)

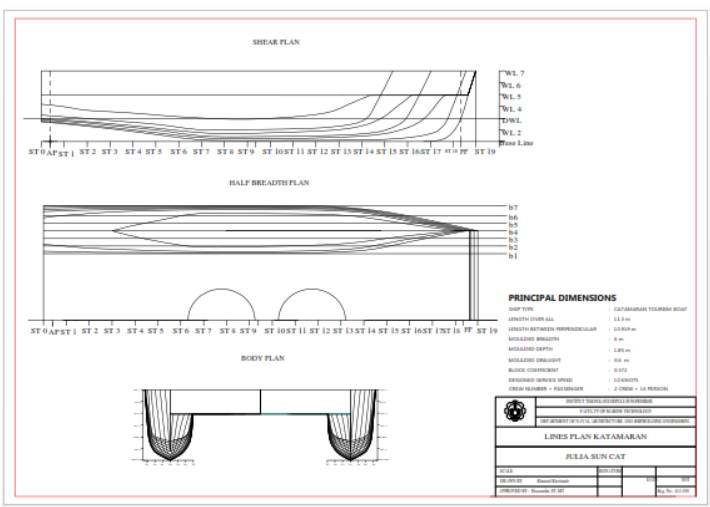

Gambar 4. Rencana Garis Julia Sun Cat Boat

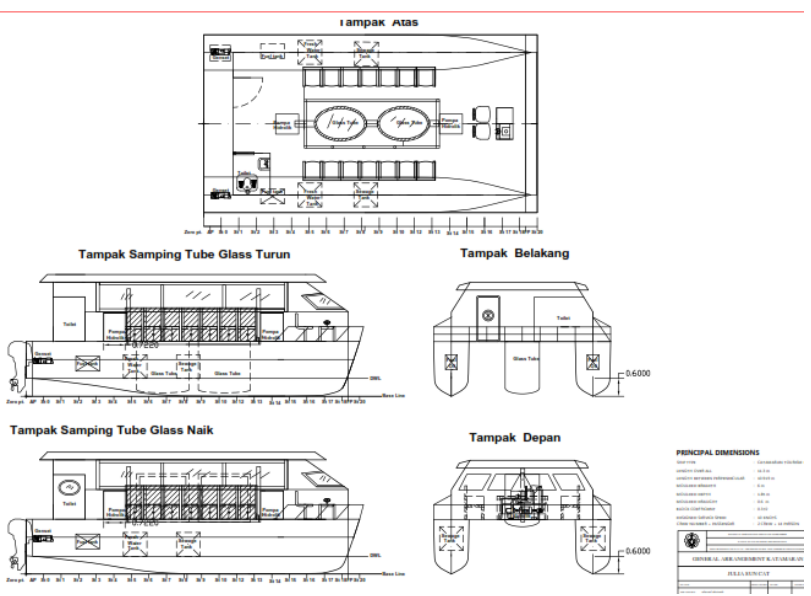

Gambar 5. Rencana Umum Julia Sun Cat Boat

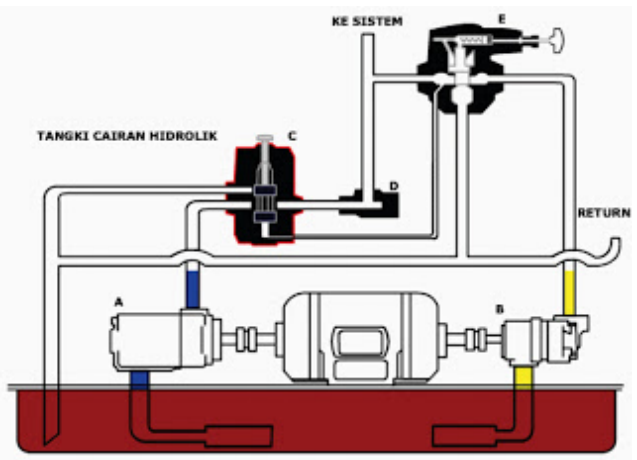

Gambar 6. Sistem Pompa Hidrolik [2]

1. Berat bahan bakar

Wfo $=$ (konsumsi bahan bakara $\mathrm{x}$ a) $/$ Vs $=0.048$ ton

2. Berat air tawar

$\mathrm{Wfw}=($ a $\times$ Ztot $\mathrm{x}$ Cfw $) / \mathrm{Vs}$

$$
=0.454 \text { ton }
$$

3. Berat Penumpang dan barang bawaan

$\mathrm{Wpb}=\mathrm{Zpb} \times \mathrm{Wpb}$

$$
=1.792 \text { ton }
$$

\section{Tebal Lambung Fiber Kapal}

Perhitungan tebal fiber kapal dilakukan dengan mengacu pada besarnya beban pada lambung kapal. Makin besar beban 
pada lambung kapal maka makin tebal lapisan. Perhitungan tebal mengacu pada aturan Lyod Register Ch.8 untuk kapal katamaran fiber

\section{E. Perhitungan Berat Kapal}

Perhitungan berat pada kapal pada umumnya terbagi menjadi dua komponen, yaitu LWT (Light Weight Tonnage) dan DWT (Dead Weight Tonnage). Hasil perhitungan untuk total berat kapal $=6.188$ ton.

\section{F. Perhitungan Freeboard}

Freeboard adalah hasil pengurangan tinggi kapal dengan sarat kapal dimana tinggi kapal termasuk tebal kulit dan lapisan kayu jika ada, dan sarat $\mathrm{T}$ didapatkan dari hasil survey.

Karena kapal katamaran memiliki panjang kurang dari 24 m. Maka untuk menghitung lambung timbul tidak dapat menggunakan ketentuan Internasional Convention on Load Lines (ICLL) 1966. Oleh sebab itu, perhitungan lambung timbul public catamaran boat menggunakan aturan NonConvention Vessel Standart (NCVS) Indonesian Flagged.Load Lines. Hasil perhitungan freeboard kapal 1.25 $\mathrm{m}$, dan kondisi diterima karena lebih dari lambung timbul yang dipersyaratkan Non-Convention Vessel Standart (NCVS) sebesar $0.31 \mathrm{~m}$.

\section{G. Perhitungan Trim}

Trim dapat didefinisikan perbedaan sarat belakang dan sarat depan. Trim terjadi sebagai akibat dari tidak meratanya momen statis dari penyebaran gaya berat. Trim dibedakan menjadi dua, yaitu trim haluan dan trim buritan. Trim haluan terjadi apabila sarat haluan lebih tinggi daripada sarat buritan. Begitu juga sebaliknya untuk trim buritan [9]. Hasil perhitungan batasan trim : $-0.326 \mathrm{~m}$, dengan batasan trim $1.0919 \mathrm{~m}$ an kondisi trim haluan diterima.

\section{H. Stabilitas kapal katamaran}

Stabilitas dapat diartikan sebagai kemampuan kapal untuk kembali ke keadaan semula setelah dikenai oleh gaya luar. Kemampuan tersebut dipengaruh oleh lengan dinamis (GZ) yang membentuk momen kopel yang menyeimbangkan gaya tekan ke atas dengan gaya berat.

Kriteria stabilitas yang digunakan adalah kriteria stabilitas untuk kapal jenis umum dan kapal penumpang yang mengacu pada Intact Stability (IS) High Speef Craft (HSC) 2000 Annex 7 Multihull dan IMO A.749 (18) Ch. 3. Kriteria tersebut antara lain sebagai berikut :

1. Luas area dibawah kurva lengan pengembali (GZ curve) antara sudut $0 \mathrm{o}-30 \mathrm{o}$ tidak boleh kurang dari 0.055 m.rad atau 3.151 m.deg.

2. Luas area dibawah kurva lengan pengembali (GZ curve) antara sudut $0 \mathrm{o}-40 \mathrm{o}$ tidak boleh kurang dari 0.090 m.rad atau 5.157 m.deg.

3. Luas area dibawah kurva lengan pengembali (GZ curve) antara sudut $30 \mathrm{o}-40 \mathrm{o}$ atau antara sudut downflooding ( f) dan 30ojika nilai GZ maksimum tidak mencapai $40 \mathrm{o}$, tidak boleh kurang dari $0.030 \mathrm{~m} . \mathrm{rad}$ atau 1.719 m.deg.
4. Lengan pengembali GZ pada sudut oleh sama dengan atau lebih dari $30 \mathrm{o}$ minimal $0.200 \mathrm{~m}$.

5. Lengan pengembali maksimum terjadi pada kondisi oleng sebaiknya mencapai $30 \mathrm{o}$ atau lebih, tetapi tidak kurang dari 150 .

6. Tinggi titik metacenter awal (GMo) tidak boleh kurang dari $0.15 \mathrm{~m}$.

Hasil dari pengecekan stabilitas untuk beberapa kondisi pemuatan dapat dilihat pada Tabel 3 .

\section{Pembuatan Rencana Garis dan Rencan Umum}

Rencana garis adalah gambar potongan melintang, memanjang dan diagonal kapal yang dilihat dari samping, depan, atas dan digambarkan dalam bentuk garis. Berikut rencana garis kapal wisata katamarn :

Rencana umum didefinisikan sebagai perencanaan ruangan yang sesuai dengan kebutuhan dengan fungsi dan perlengkapannya [8]. Pembuatan rencana umum kapal didasarkan pada peletakkan kamar mesin, kebutuhan akomodasi, serta peletakan tangki-tangki yang dibutuhkan.

\section{J. Sistem Pompa Hidrolik}

Dalam desain kapal wisata ini akan dibuat kapal katamaran dengan fasilitas tabung gelas kaca yang bisa dinaikkan dan diturunkan pada waktu tertentu dengan pompa hidrolik untuk melihat taman bawah laut pada kedalaman $0.6 \mathrm{~m}$ di bawah permukaan air.

Sistem hidrolik adalah teknologi yang memanfaatkan zat cair, biasanya oli, untuk melakukan suatu gerakan segaris atau putaran. Sistem ini bekerja berdasarkan prinsip Pascal, yaitu jika suatu zat cair dikenakan tekanan, tekanan itu akan merambat ke segala arah dengan tidak bertambah atau berkurang kekuatannya.

\section{K. Komponen Utama Sistem Hidrolik}

Sistem hidrolik ini didukung oleh 3 unit komponen utama, yaitu:

1. Unit Tenaga, berfungsi sebagai sumber tenaga dengan liquid/ minyak hidrolik

Pada sistem ini, unit tenaga terdiri atas:

a. Penggerak mula yang berupa motor listrik atau motor bakar

b. Pompa hidrolik, putaran dari poros penggerak mula memutar pompa hidrolik sehingga pompa hidrolik bekerja

c. Tangki hidrolik, berfungsi sebagai wadah atau penampang cairan hidrolik

d. Kelengkapan (accessories), seperti : pressure gauge, gelas penduga, relief valve

2. Unit Penggerak (Actuator), berfungsi untuk mengubah tenaga fluida menjadi tenaga mekanik

Hidrolik actuator dapat dibedakan menjadi dua macam yakni:

a. Penggerak lurus (linier Actuator) : silinder hidrolik

b. Penggerak putar : motor hidrolik, rotary actuator

c. Unit Pengatur, berfungsi sebagai pengatur gerak sistem hidrolik. 


\section{Analisa Ekonomis Kapal Katamaran}

Dalam analisa ekonomi kali ini, akan dilakukan perhitungan untuk biaya pembangunan kapal, biaya operasional, NVP, IRR, dan BEP.

\section{1) Biaya Pembangunan kapal}

Dari hasil perhitung biaya pembangunan kapal terdiri dari beberapa komponen, yaitu biaya baja kapal, biaya peralatan yang digunakan, biaya motor kapal, dan sebagainya. Hasil Perhitungan biaya pembangunan kapal sebesar $\mathrm{Rp}$ 732,918,893.35,

\section{2) Biaya Operasional}

Operational cost merupakan biaya yang harus dikeluarkan owner kapal secara rutin. Pada Tugas Akhir ini, perhitungan operational cost ditentukan untuk biaya rutin yang harus dikeluarkan owner kapal setiap tahun. Beberapa faktor yang mempengaruhi besarnya operational cost di antaranya biaya perawatan kapal, asuransi, gaji kru kapal, cicilan pinjaman bank, serta biaya bahan bakar. Hasil perhtiungan biaya Operasional kapal selam satu tahun sebesar Rp. 492,656,359

3) Analisa Investasi

Perhitungan biaya investasi dilakukan untuk mengetahui apakah pembagunan kapal ini layak untuk dilakukan sesuai dengan periode yang ditentukan. Net Present Value (NPV) dan IRR (Internal Rate of Return). Nilai NPV > 0, dan IRR > suku bunga maka dari itu investasi proyek dikatakan layak.

\section{4) Penentuan Harga Tiket}

Penentuan harga tiket kapal wisata berdasarkan harga tiket yang telah berlaku untuk wisata Bangsring, dengan turut mempertimbangkan biaya operasioanal dan pembangunan kapal. Maka ditentukan harga tiket Rp. 310.000 per orang untuk satu kali trip

\section{5) Perhitungan Break Event Point}

Dalam ilmu ekonomi, terutama akutansi biaya, titik impas (break event point) adalah sebuah titik dimana biaya atau pengeluaran dan pendapatan adalah seimbang sehingga tidak terdapat kerugian atau keuntungan. Dari hasil perhtiungn BEP terjadi pada tahun 4 tahun.

\section{KESIMPULAN}

\section{A. Kesimpulan}

Dari hasil survey, desain kapal wisata untuk wisata Pantai Bangsring adalah kapal wisata katamaran fiberglass dengan rute Bangsring - P.Menjangan - P. Tabuhan. Berikut hasil analisa teknis dan ekonomis:

1. Analisa Teknis kapal wisata, ukuran utama kapal $\mathrm{L}=$ $11.3 \mathrm{~m}, \mathrm{Lwl}=10.919 \mathrm{~m}, \mathrm{~B}=6 \mathrm{~m}, \mathrm{~T}=0.6 \mathrm{~m}, \mathrm{H}=1.85$ $\mathrm{m}, \quad \mathrm{S}=3.6 \mathrm{~m}, \mathrm{Vs}=10 \mathrm{knot}, \Delta=6.4$ ton, jumlah penumpang $=14$ orang dan crew kapal $=2$ orang. Dan hambatan kapal sebesari $3.49 \mathrm{kN}$, maka BHP yang dibutuhkan $51.57 \mathrm{HP}$

2. Trim kapal : trim haluan, memenuhi batasan trim dengan nilai trim -0.326 , dan

3. Perhitungan freeboard memenuhi aturan NonConvention Vessel Standard Indonesia Flagged Chapter VI dengan nilai freeboard $1.25 \mathrm{~m}$.
4. Analisa ekonomi : Biaya Pembangunan kapal sebesar Rp. 732,918,893.35, Biaya operasional sebesar Rp. 492,656,359 per tahun dan investasi proyek layak dilakukan karena nilai NPV $>0$ sebesar Rp. 230,528,599.25, IRR memenuhi sebesar $15.28 \%$, BEP akan dicapai dalam 4 tahun dengan harga tiket Rp. 310.000 per orang untuk sekali trip

\section{B. Saran}

Dalam desain kapal wisata untuk rute Bangsring - P. Menjangan - P. Tabuhan terbatas hanya pada analisa teknis dan ekonomis, maka diharapkan untuk penelitian selanjutnya dilakukan pembahasan mengenai:

1. Perhitungan berat konstruksi agar dilakukan dengan lebih terperinci agar hasil yang didapatkan lebih akurat dan mendekati keadaan yang sebenarnya.

2. Perlu dilakukan pemeriksaan material konstruksi lebih lanjut untuk mengetahui kekuatan struktur konstruksi kapal.

3. Perlu dilakukan perhitungan mengenai kekuatan struktur dari kapal katamaran dengan adanya lubang di tengah geladaknya.

\section{UCAPAN TERIMAKASIH}

Penulis mengucapkan terimakasih kepada ALLAH SWT yang telah memberikan nikmat berupa karunia ilmu dan kesehatan sehingga penulis bisa menyelesaikan Tugas Akhir ini, dan kepada orang tua tercinta yaitu Bapak Hasan dan Emak Maryati, yang memberikan kasih sayang dan didikan mulai dari penulis kecil hingga besar, dosen pembimbing Tugas Akhir Bapak Hasanudin yang selalu memberikan arahan demi kelancaran pengerjaan Tugas Akhir sampai akhir, serta ibu dan bapak dosen penguji selama sidang P1 - P3 berakhir.

\section{DAFTAR PUSTAKA}

[1] Arianto, Wisnu. "Desain Kapa Wisata 1 Katamaran untuk Kepulauan Karimun Jawa ." POMITS, 2015: 1.

[2] Nurhadi, Rusman. 2016. Sistem Hidrolik. System Mutu Engineering Department.

[3] Fyson J. 1985. Design of Small Fishing Ve s s e 1 s . England : Fishing News Book.

[4] Lewis, Edward V.1988.Principle of Naval Architecture Second Revision Vol : II Resistance, Propulsion and Vibration. The Society of Naval Architects and Marine Engineers 601 Pavonia Avenue jersey City, NJ

[5] Molland, M., and A. F. Insel. "An Investigation Into the Resistance Components of High Speed Displacement Catamarans." RINA, 1992.

[6] Nurcahyadi, M. 2010.Tekno Ekonomi Pembuatan Perahu Fiberglass di Desa Cikahuripan, Kecamatan Cisolok, Sukabumi. Bogor. Departemen Pemanfaatan Sumberdaya Perikanan, Fakultas Perikanan dan Ilmu Kelautan, IPB

[7] Santosa, I.G.M (1999). Diktat Kuliah Perencanaan Kapal. Surabaya: Jurusan Teknik Perkapalan, Fakultas Teknologi Kelautan, Institut Teknologi Sepuluh Nopember

[8] Taggart, Robert. Ship Design and Construction. New York: The Society of Naval Architects and Marine Engineers, 1980.

[9] Watson, D. G. M., and A. W. Gilfillan. Parametric Design. Oxford: Transaction RINA, 1977.

[10] Yulianto, ES.2010. Desain Perahu Fiberglass Bantuan LPPM IPB di Desa Cikahuripan. Kecamatan Cisolok. Sukabumi (skripsi). Bogor: Fakultas Perikanan dan ilmu Kelautan, Institut Pertanian Bogor 
JURNAL TEKNIK ITS Vol. 5, No. 2, (2016) ISSN: 2337-3539 (2301-9271 Print) 